\title{
GAMBARAN KOMUNIKASI INTERPERSONAL GURU MATA PELAJARAN DENGAN GURU BIMBINGAN DAN KONSELING DI SMPN 1 JAKARTA
}

\author{
Jamilah $^{1}$ \\ Dra. Dra. Michiko Mamesah, M.Psi ${ }^{2}$ \\ Dr. Awaluddin Tjalla ${ }^{3}$
}

\begin{abstract}
Abstrak
Penelitian ini bertujuan untuk mengetahui gambaran komunikasi interpersonal guru mata pelajaran dengan guru BK di SMP Negeri 1 jakarta. Penelitian dilaksanakan dengan subjek penelitian 34 orang guru mata pelajaran dengan menggunakan teknik sampling jenuh. . Instrumen yang digunakan dalam penelitian ini adalah kuesioner . Berdasarkan hasil penelitian bahwa komunikasi interpersonal guru mata pelajaran di SMP Negeri 1 Jakarta masuk dalam kategori sedang dengan persentase 64,71\% Data ini ditunjukkan dengan hasil kategorisasi dimana persentase terbesar pada masing-masing aspek berada pada kategori sedang, yaitu aspek keterbukaan dengan persentase 91,18\%, Aspek empati dengan persentase 76,47\%, kemudian aspek sikap mendukung dengan persentase 79,41\%, lalu aspek sikap positif dengan persentase $76,47 \%$, dan aspek kesetaraan dengan persentase $73,53 \%$. Hasil ini menunjukkan bahwa penelitian ini dapat dijadikan informasi bagi guru mata pelajaran untuk dapat melakukan upaya meningkatkan aspek komunikasi interpersonal yang belum optimal. Hal ini dapat dilakukan dengan cara turut berpartisipasi dalam seminar maupun pelatihan-pelatihan yang dapat menunjang komunikasi interpersonal yang ada pada diri guru mata pelajaran. Apabila penelitian ini tidak dilakukan maka tidak akan diketahui kondisi komunikasi interpersonal guru mata pelajaran dengan guru BK. Hal ini berdampak tidak adanya evaluasi pada guru mata pelajaran di SMP Negeri 1 Jakarta.
\end{abstract}

Kata Kunci: Komunikasi Interpersonal, Guru.

\section{Pendahuluan}

Komunikasi merupakan salah satu cara terpenting untuk berhubungan dan mengadakan kontak dengan orang lain. Salah satu jenis komunikasi yang dianggap penting adalah komunikasi interpersonal. Suranto mengungkapkan bahwa salah satu jenis komunikasi yang frekuensi terjadinya cukup tinggi adalah komunikasi interpersonal atau komunikasi antar pribadi.

Bowes (2008), dalam artikelnya yang berjudul "Building Effective Communicators" menyatakan bahwa sebagian besar masalah yang terjadi di tempat kerja disebabkan oleh komunikasi interpersonal yang buruk antar pegawai ataupun

1 Mahasiswa Jurusan Bimbingan dan Konseling FIP UNJ, jamilahalaidied@gmail.com

2 Dosen Bimbingan dan Konseling FIP UNJ, michikomamesah@yahoo.com

3 Dosen Bimbingan dan Konseling FIP UNJ, awaluddintjalla@yahoo.com 
dengan atasannya. Artinya, dalam lingkungan sekolah hubungan antara guru dengan kepala sekolah atau sesama guru dan staf harus terjalin komunikasi yang baik sehingga tidak timbul permasalahan di dalam lingkungan sekolah.

Dalam ayat 7 Kode Etik Guru disebutkan bahwa "Guru memelihara hubungan seprofesi, semangat kekeluargaan, dan kesetiakawanan sosial". Hal ini menunjukkan betapa pentingnya hubungan yang harmonis perlu diciptakan dengan mewujudkan perasaan bersaudara yang mendalam antara sesama profesi.

Agar pelayanan yang diberikan oleh guru BK terhadap siswa dapat berjalan secara efektif, maka guru BK memerlukan bantuan dan kerjasama dengan seluruh tenaga pengajar dan tenaga kependidikan lainnya yang ada di sekolah khususnya dengan guru mata pelajaran.

Hasil wawancara terhadap guru BK SMPN 1 Jakarta terkait komunikasi interpersonal dengan guru mata pelajaran di sekolah didapatkan informasi bahwa guru BK mendapatkan beberapa permasalahan terkait dengan komunikasi interpersonal yang buruk diantara guru mata pelajaran dengan guru BK dalam menangani permasalahan siswa di sekolah.

Bedasarkan hal tersebut di atas, maka rumusan masalah dalam penelitian ini adalah mengenai: "Bagaimana Gambaran Komunikasi Interpersonal guru mata pelajaran dengan guru BK di SMPN 1 Jakarta?"

Tujuan mengadakan penelitian ini yaitu untuk melihat bagaiamana gambaran komunikasi interpersonal guru mata pelajaran dengan guru BK Sehingga dapat terjalin kerjasama yang baik dalam menangani permasalahan siswa di sekolah.

\section{Kajian Teori}

Hakikat Komunikasi Interpersonal Komunikasi interpersonal dianggap oleh beberapa ahli paling efektif dalam upaya mengubah sikap, pendapat, atau prilaku seseorang karena sifatnya yang logis dan berupa percakapan. Joseph A. Devito mendefinisikan bahwa, "Interpersonal communication is communication that takes place between two persons who have an established relationship; the peo- ple are in some way "connected".

Dalam hal ini komunikasi interpersonal meliputi komunikasi yang terjadi antara rekan kerja.

Joseph A. Devito mengemukakan evektifitas komuniksi interpersonal dimulai dengan lima kualitas umum yang dipertimbangkan, yaitu:

1. Keterbukaan (openness), yaitu sejauh mana individu memiliki keinginan untuk terbuka dengan orang lain dalam berinteraksi. Kualitas keterbukaan mengacu pada sedikitnya tiga aspek dari komunikasi antar pribadi, yaitu:

a. Adanya kesediaan komunikator untuk membuka diri.

b. Kesediaan komunikator untuk bereaksi secara jujur.

c. Menyangkut kepemilikan, perasaan dan pikiran.

2. Empati (empathy), yaitu merasakan sesuatu seperti yang mengalaminya. empati akan membuat seseorang lebih mampu menyesuaikan komunikasinya.

3. Sikap mendukung (supportiveness), adanya dukungan dapat membantu seseorang lebih bersemangat dalam melakukan aktivitas serta meraih tujuan yang diinginkan. Hal ini dapat terlihat dengan cara bersikap:

a. Deskriptif dan bukan evaluative.

b. Spontan bukan strategic.

c. Provisional dan bukan sangat yakin.

4. Rasa positif (possitiveness), yaitu menyatakan sikap secara positif terhadap diri maka situasi akan mendorong orang lain juga untuk merefleksikan perasaan positif.

5. Kesetaraan (equality), komunikasi antarpribadi akan lebih efektif bila suasananya setara.

\section{Hakikat Guru}

Guru adalah salah satu komponen dalam proses belajar mengajar yang ikut berperan dalam usaha pembentukan individu yang potensial untuk dapat membangun bangsa.

Seorang guru wajib memiliki kualifikasi akademik, kompetensi, sertifikat pendidik, sehat jasmani dan rohani, serta memiliki kemampuan untuk mewujudkan tujuan pendidikan nasional. Kompetensi yang harus dimiliki oleh seorang guru meliputi: 
1. Kompetensi pedagogic

2. kompetensi kepribadian

3. kompetensi sosial

4. kompetensi professional

Guru BK merupakan seorang tenaga kependidikan yang memiliki tugas, tanggung jawab, wewenang dan hak secara penuh dalam melaksanakan layanan BK di sekolah terhadap sejumlah peserta didik.

Guru mata pelajaran adalah seorang tenaga pendidik professional yang mengajar mata pelajaran tertentu dan memiliki peran, tugas, dan tanggung jawab untuk merencanakan, melaksanakan proses pengajaran, menilai hasil pembelajaran suatu mata pelajaran tertentu, serta membimbing siswanya untuk dapat mengembangkan potensi siswa. Guru mata pelajaran merupakan mitra bagi guru BK di dalam penanganan siswa secara optimal. Selain melaksanakan tugasnya guru mata pelajaran juga memiliki peran membantu guru BK dalam pelaksanaan program bimbingan dan konseling. Berikut adalah uraian tugas atau peran guru mata pelajaran dalam kaitannya dengan pelayanan BK oleh Direktorat Jendral Peningkatan Mutu Pendidikan dan Tenaga Kependidikan (2007:71):

1) Membantu guru BK mengidentifikasi siswa yang memerlukan bimbingan dan konseling, serta membantu dalam pengumpulan data siswa.

2) Mereferal siswa yang memerlukan bantuan pelayanan BK.

3) Menerima siswa alih tangan dari guru BK.

4) Memberikan kesempatan dan kemudahan kepada siswa yang memerlukan pelayanan BK.

5) Berpartisipasi dalam kegiatan khusus penanganan masalah siswa, seperti konferensi kasus.

6) Membantu mengumpulkan informasi yang diperlukan dalam rangka penilaian BK serta upaya tindak lanjutnya.

\section{Metode Penelitian}

Penelitian dilakukan di SMPN 1 Jakarta. Penelitian dilaksanakan pada bulan Maret-November 2014 tahun ajaran 2014-2015. Adapun subjek dalam penelitian ini melibatkan 34 guru mata pelajaran. Teknik sampling yang digunakan yaitu sampling jenuh.
Metode yang digunakan dalam penelitian ini adalah metode deskriptif. Arikunto mengemukakan bahwa pendekatan deskriptif merupakan penelitian yang dimaksudkan untuk menyelidiki keadaan atau kondisi yang apa adanya pada saat penelitian dilakukan.

Penelitan ini menggunakan teknik survei. Teknik survei adalah teknik yang sempurna untuk mendeskripsikan sikap, pendapat orang-orang. Penelitian ini menggunakan variabel komunikasi interpersonal yang disusun berdasarkan teori Joseph A. DeVito dengan aspek 1) keterbukaan, 2) Empati, 3) Sikap Mendukung, 4) Sikap Positif, dan 5) Kesetaraan.

Teknik pengumpulan data pada penelitian ini adalah dengan teknik non-tes, dengan menggunakan teknik skala likert. Sebelum instrumen digunakan untuk memperoleh data, terlebih dahulu diujicobakan kepada sampel uji. Hal ini bertujuan untuk mengetahui kelayakan dan ketepatan instrumen sebagai alat pengumpul data. Jumlah subjek yangdiujicobakan sebanyak 31 guru mata pelajaran, yang memiliki karakteristik yang sama dengan populasi yang hendak diteliti, yaitu guru SMP Negeri 47 Jakarta.

Uji coba instrumen berjumlah 64 butir pernyataan yang terdiri dari 32 pernyataan negatif dan 32 pernyataan positif. Hasil butir angka yang dikonstruksikan pada $r$ tabel product moment pada taraf signifikansi 5\% yaitu 0,355. Dari pelaksanaan uji coba ini diperoleh data bahwa terdapat 48 butir yang dinyatakan valid dan 16 butir yang dinyatakan tidak valid (drop).

Angka reliablitas yang diperoleh berdasarkan perhitungan didapatkan hasil 0,764. Berdasarkan tabel interpretasi nilai reliabilitas dapat dikatakan bahwa instrumen ini layak untuk digunakan sebagai alat pengumpul data dalam penelitian.

Penyajian data dari hasil penelitian akan dikategorisasikan dalam tiga kategorisasi yaitu tinggi, sedang dan rendah.

\section{Hasil dan Pembahasan}

Data dalam penelitian ini diperoleh melalui penyebaran instrumen kepada 34 orang guru mata pelajaran di SMPN 1 Jakarta. Hasil yang diperoleh 
dari menyebar instrumen komunikasi interpersonal yang berisi 48 Butir pernyataan adalah seba-nyak 22 responden berada pada kategori sedang, dengan persentase $64,71 \%$. Selanjutnya, 5 responden berada pada kategori tinggi dengan persentase 14,71\%. Tujuh responden lainnya berada pada kategori rendah yang dapat diartikan kurang mampu dalam berkomunikasi interpersonal, dengan persentase $20,58 \%$.

Tabel 1.1 Kategorisasi Komunikasi Interpersonal Guru Mata Pelajaran dengan Guru BK di SMP Negeri 1 Jakarta

\begin{tabular}{|c|c|c|c|}
\hline Kategori & Skor & Frekuensi & Persentase \\
\hline Tinggi & $>114$ & 5 & $14,71 \%$ \\
\hline Sedang & $102-113$ & 22 & $64,71 \%$ \\
\hline Rendah & $<101$ & 7 & $20,58 \%$ \\
\hline \multicolumn{2}{|c|}{ Total } & $\mathbf{3 4}$ & $\mathbf{1 0 0 , 0 0 \%}$ \\
\hline
\end{tabular}

Gambar 1.1

Persentase Komunikasi Interpersonal pada Guru Mata Pelajaran dengan Guru BK di SMP Negeri 1 Jakarta per Aspek

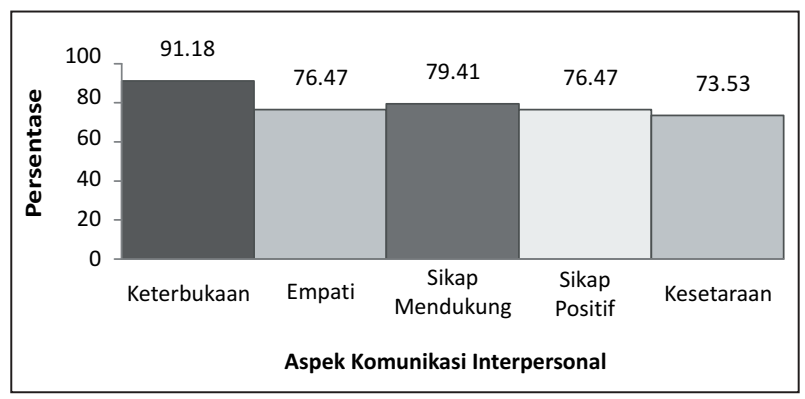

Berdasarkan penelitian yang telah dilakkan untuk mengukur gambaran komunikasi interpersonal guru mata pelajaran dengan guru BK menunjukkan, bahwa komunikasi interpersonal guru mata pelajaran di SMP Negeri 1 berada pada kategori sedang dengan persentase $64,71 \%$. Dilihat dari segi aspeknya, persentase gambaran komunikasi interpersonal guru mata pelajaran dan guru BK di SMP Negeri 1 Jakarta yaitu keterbukaan memperoleh persentase $91,18 \%$, empati memperoleh persentase $76,47 \%$, sikap mendukung memperoleh persentase $79,41 \%$, sikap positif memperoleh persentase $76,47 \%$, dan kesetaraan memperoleh persentase 73,53\%.

Pada hasil penelitian ini yang memperoleh persentase tertinggi adalah aspek keterbukaan. Hal ini dibuktikan dengan pada setiap indikatornya memperoleh persentase di atas 79\%, yakni $94,12 \%$ responden dapat bereaksi secara jujur. Kemudian $85,30 \%$ dilanjutkan oleh indikator bersedia membuka diri, dan terendah adalah indikator dapat bertanggung jawab terhadap perasaan dan pikiran dengan persentase $79,41 \%$.

Hal ini senada dengan yang dikemukakan oleh Gerald Miller dan M. Steinberg dalam Wiryanto yang mendefinisikan komunikasi interpersonal dalam pengertian penetrasi. Semakin banyak komunikator mengetahui satu sama lain, maka semakin banyak karakter antarpribadi yang terbawa di dalam komunikasi tersebut. Oleh karena itu komunikasi interpersonal adalah proses sesungguhnya dari penetrasi sosial.

Pada aspek keterbukaan mendapatkan persentase sebanyak 91,18\%. Hal ini ditandai dengan guru mata pelajaran sudah mampu membuka diri. Dibuktikan dengan guru mata pelajaran cukup mampu membangun hubungan yang baik dengan guru BK serta terbuka untuk berbagi dengan guru BK mengenai pengalaman hidup, tetap mengemukakan pendapatnya walaupun pendapatnya berbeda dengan pendapat guru BK, serta guru mata pelajaran akan menyatakan apabila kurang memahami penjelasan yang diberikan guru BK, guru mata pelajaran mempertimbangkan saran yang akan diberikan kepada guru BK serta guru mata pelajaran akan mempertimbangkan dahulu apabila ingin mengkritik guru BK.

Pada aspek empati, sebanyak 76,47\% responden mampu menunjukkan perasaan yang dirasakan orang lain secara verbal maupun non-verbal, hal ini dibuktikan dengan guru mata pelajaran akan ikut merasakan apa yang dirasakan oleh guru bimbingan dan konseling ketika melihat guru BK terlihat memiliki masalah pribadi, begitu juga ketika guru BK sedang menangani permasalahan siswa disekolah guru mata pelajaran akan menawarkan bantuan untuk membantu menyelesaikan permasalahan siswa.

Selanjutnya pada aspek sikap mendukung mendapatkan pesentase sebanyak $79,41 \%$. Hal ini dibuktikan dengan guru mata pelajaran cukup mampu mengemukakan perasaan dan pikiran secara terus terang buktikan dengan guru mata pelajaran adalah orang yang spontan dalam berkomunikasi, guru mata pelajaran dapat memberikan saran atau kritik apa 
adanya kepada guru BK, guru mata pelajaran cukup dapat memberikan informasi yang dibutuhkan guru BK mengenai siswa yang memerlukan bantuan BK.

Kemudian pada aspek sikap positif mendapatkan persentase sebanyak 76,47\%. Hal ini dibuktikan dengan guru mata pelajaran cukup mampu memberikan ucapan selamat kepada guru BK yang berprestasi, serta guru mata pelajaran akan memberikan senyum kepuasan ketika guru BK cepat tanggap dalam memberikan layanan kepada siswa.

Terakhir, aspek kesetaraan, memperoleh persentase terkecil sebanyak 73,53\%. Dibuktikan dengan guru mata pelajaran di SMP Negeri 1 Jakarta cukup mampu menyadari akan adanya kepentingan yang berbeda di antara guru BK dengan guru mata pelajaran. Hal ini ditandai dengan guru mata pelajaran mampu mendengarkan pendapat yang berbeda dari guru bimbingan dan konseling, guru mata pelajaran menyadari bahwasanya guru BK harus mendapatkan pengakuan dan haknya seperti guru lain, serta guru mata pelajaran merasa terbantu dengan keikutsertaan guru BK dalam menangani permasalahan siswa yang mengalami kesulitan belajar.

\section{Simpulan dan Saran}

Penelitian yang telah dilakukan memberikan kesimpulan bahwa gambaran komunikasi interpersonal guru mata pelajaran dengan guru BK di SMP Negeri 1 masuk pada kategori sedang, dapat diartikan cukup baik namun butuh untuk ditingkatkan agar komunikasi interpersonal dengan kolega disekolah terutama guru BK dapat berjalan lebih baik dan efektif. Sehingga dapat terjalin kerjasama yang baik antara guru mata pelajaran dengan guru BK, dengan begitu guru mata pelajaran dapat membantu guru BK dalam menyelenggarakan la-yanan bimbingan dan konseling yang efektif. Apabila penelitian ini tidak dilakukan, tidak akan diketahui kondisi komunikasi interpersonal guru mata pelajaran di SMP Negeri 1 Jakarta. Hal tersebut berdampak tidak adanya evaluasi mengenai komunikasi interpersonal pada guru mata pelajaran di SMP Negeri 1 Jakarta.

Adapun saran-saran yang dibuat untuk penelitian lanjutan adalah sebagai berikut:

1. Peneliti selanjutnya dapat mengembangkan se- buah alat untuk mengisi kekosongan alur komunikasi dalam laporan permasalahan siswa dari guru mata pelajaran kepada guru BK dengan membuat kotak masalah serta kertas yang disediakan di ruang guru, sebagai bentuk laporan dengan menggunakan media statis berbentuk tulisan untuk menghindari mis-communication dalam menangani permasalahan siswa. Kertas laporan tersebut juga dapat digunakan sebagai data laporan permasalahan siswa bagi guru BK.

2. Bagi guru mata pelajaran, dapat menjadikan hasil penelitian ini sebagai informasi mengenai gambaran komunikasi interpersonal yang dimiliki-nya, sehingga dapat melakukan upayaupaya yang bertujuan untuk meningkatkan aspek kemampuan komunikasi interpersonal yang masih belum optimal dalam dirinya dengan turut berpartisipasi atau mengikuti seminar maupun pelatihan-pelatihan yang dapat menunjang kemampuan komunikasi interpersonal yang ada pada diri guru mata pelajaran.

3. Bagi guru BK, penelitian ini dapat dijadikan masukan bagi guru BK untuk terus mensosialisasikan peran dan fungsi BK di lingkungan sekolah, sehingga keprofesioanalan guru BK di sekolah diakui keberadaannya oleh guru mata pelajaran. Guru BK juga harus mampu merangkul guru mata pelajaran sebagai partner kerja di lingkungan sekolah dengan menjalin komunikasi interpersonal atas dasar kebutuhan siswa. Apabila hal ini dapat tercapai tentu saja akan banyak membantu guru BK dalam melakukan pekerjaannya.

4. Bagi institusi sekolah, penelitian ini dapat dijadikan informasi untuk dapat mengembangkan aktivitas pada guru dalam kelompok organisasi guru, sehingga guru-guru memiliki kesempatan dalam mengembangkan komunikasi interpersonal.

5. Bagi jurusan BK, penelitian ini dapat dijadikan dasar evaluasi pada proses pembelajaran agar dapat meningkatkan kualitas pembelajaran mengenai komunikasi interpersonal sehingga dapat menghasilkan guru BK yang profesional. Hal ini dapat dilakukan

6. Dengan memberikan format evaluasi pre-test dan post-test pada mata kuliah komunikasi antar pribadi, sehingga diperoleh gambaran perkem- 
bangan komunikasi pada diri mahasiswa atau calaon guru BK.

\section{Daftar Pustaka}

Arikunto, Suharsimi. 2010. Prosedur Penelitian Suatu praktek. Jakarta: Rienekas Cipta.

Bowes, Barbara. 2008. Building Effective Communicators. CMA Management.

Devito, Joseph A. 1995. The Interpersonal Communication Book. Seventh Edition, New York: HarpeCollins College Publishers.
Kunandar. 2008. Guru Profesional Implementasi Kurikulum tingkat satuan pendidikan (KTSP) dan Sukses dalam Sertifikasi Guru. Jakarta: Raja Grafindo Persada.

Shaugnessy, John dkk. 2007. Metodologi Penelitian Psikologi Edisi ketujuh. Yogyakarta: Pustaka Belajar.

Soetjipto. 2009. Profesi Keguruan. Jakarta: Rineka Cipta.

Suranto, A. W.. 2011. Komunikasi Interpersonal. Yogyakarta: Graha Ilmu. 